\title{
Correction: The dominant Anopheles vectors of human malaria in the Americas: occurrence data, distribution maps and bionomic précis
}

\author{
Marianne E Sinka ${ }^{1 *}$, Yasmin Rubio-Palis ${ }^{2,3}$, Sylvie Manguin ${ }^{4}$, Anand P Patil ${ }^{1}$, Will H Temperley ${ }^{1}$, Peter W Gething ${ }^{1}$, \\ Thomas Van Boeckel ${ }^{1,5}$, Caroline W Kabaria ${ }^{6}$, Ralph E Harbach ${ }^{7}$ and Simon I Hay ${ }^{1,6^{*}}$
}

\section{Correction}

In our original publication detailing the distribution of the dominant vector species of malaria in the Americas (Sinka et al. [1]), both Figure one (The predicted distribution map of $A n$. darlingi) and the An. darlingi map shown in Additional file two (The predicted distribution maps of the nine dominant vector species of the Americas) included points on the border between Costa Rica and Nicaragua. These are confirmed absence points and therefore should not have been included. These maps are intended to indicate locations only where the species presence has been confirmed. Anopheles darlingi has never been found or reported from Costa Rica or Nicaragua (as indicated in the Expert opinion map) despite numerous and comprehensive surveys in the area trying to locate it.

Copies of the corrected figure and the updated Additional file can be found in Figure 1 and Additional file 1 (in this publication) and are also available on the Malaria Atlas Project (MAP) website:

Figure One:

http://www.map.ox.ac.uk/media/PDF/Figure\%201\%20\%20An\%20darlingi\%20-\%20corrected.png

Additional File Two (all species maps):

http://www.map.ox.ac.uk/media/PDF/Sinka\%20et\% 20al_Additional\%20file\%202\%20-\%20final\%20maps\%20 (FINAL).pdf

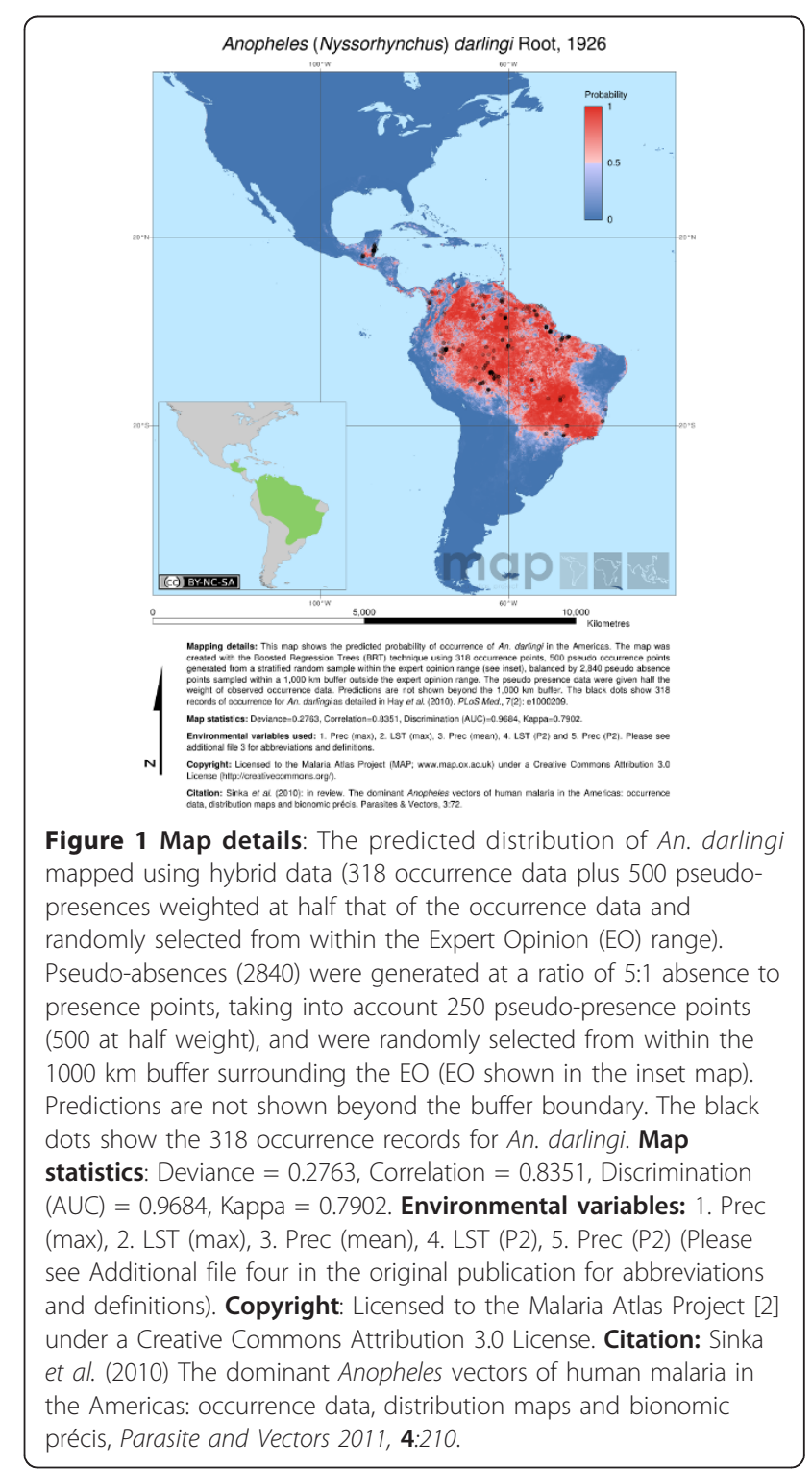

\footnotetext{
* Correspondence: marianne.sinka@zoo.ox.ac.uk; simon.hay@zoo.ox.ac.uk ${ }^{1}$ Spatial Ecology and Epidemiology Group, Tinbergen Building, Department of Zoology, University of Oxford, South Parks Road, Oxford OX1 3PS, UK Full list of author information is available at the end of the article
} 


\section{Additional material}

Additional file 1: Predictive species distribution maps for the nine DVS of the Americas.

\section{Author details}

${ }^{1}$ Spatial Ecology and Epidemiology Group, Tinbergen Building, Department of Zoology, University of Oxford, South Parks Road, Oxford OX1 3PS, UK. ${ }^{2}$ BIOMED, Universidad de Carabobo, Apartado 2073, Maracay 2101-A, Venezuela. ${ }^{3}$ Laboratorio de Ecología de Vectores, Dirección de Control de Vectores y Fauna Nociva, Ministerio del Poder Popular para la Salud, Maracay, Venezuela. ${ }^{4}$ Institut de Recherche pour le Développement, Lab. d'Immuno-Physiopathologie Virale et Moleculaire, UMR-MD3/Univ. Montpellier I, Faculté de Pharmacie, 15, Ave Charles Flahault, 34093 Montpellier, France. ${ }^{5}$ Biological Control and Spatial Ecology, Université Libre de Bruxelles CP160/12, Av FD Roosevelt 50, B1050, Brussels, Belgium. ${ }^{6}$ Malaria Public Health and Epidemiology Group, Centre for Geographic Medicine, KEMRI - Univ. Oxford - Wellcome Trust Collaborative Programme, Kenyatta National Hospital Grounds, P.O. Box 43640-00100 Nairobi, Kenya.

${ }^{7}$ Department of Entomology, The Natural History Museum, Cromwell Road, London, UK.

Received: 28 October 2011 Accepted: 3 November 2011

Published: 3 November 2011

\section{Reference}

1. Sinka ME, Rubio-Palis Y, Manguin S, Patil AP, Temperley WH, et al: The dominant Anopheles vectors of human malaria in the Americas: occurrence data, distribution maps and bionomic précis. Parasit Vectors 2010, 3:72.

doi:10.1186/1756-3305-4-210

Cite this article as: Sinka et al:: Correction: The dominant Anopheles vectors of human malaria in the Americas: occurrence data, distribution maps and bionomic précis. Parasites \& Vectors 2011 4:210.

\section{Submit your next manuscript to BioMed Central} and take full advantage of:

- Convenient online submission

- Thorough peer review

- No space constraints or color figure charges

- Immediate publication on acceptance

- Inclusion in PubMed, CAS, Scopus and Google Scholar

- Research which is freely available for redistribution

Submit your manuscript at www.biomedcentral.com/submit
C Biomed Central 